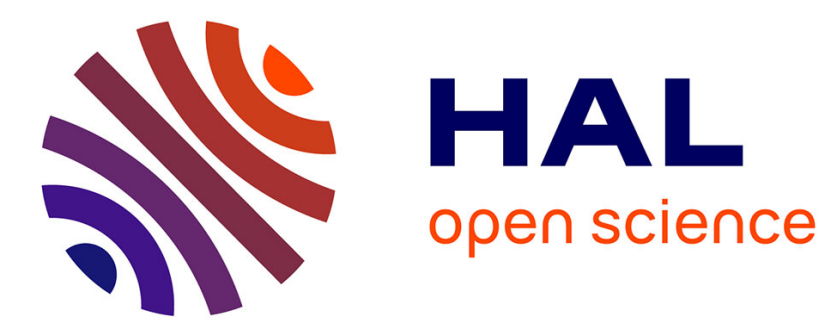

\title{
Perceptions of Self and Group in the Context of a Threatened National Identity: A Field Study
}

James E. Cameron, Julie M. Duck, Deborah J. Terry, Richard N. Lalonde

\section{To cite this version:}

James E. Cameron, Julie M. Duck, Deborah J. Terry, Richard N. Lalonde. Perceptions of Self and Group in the Context of a Threatened National Identity: A Field Study. Group Processes and Intergroup Relations, 2005, 8 (1), pp.73-88. 10.1177/1368430205048618 . hal-00571593

\section{HAL Id: hal-00571593 \\ https://hal.science/hal-00571593}

Submitted on 1 Mar 2011

HAL is a multi-disciplinary open access archive for the deposit and dissemination of scientific research documents, whether they are published or not. The documents may come from teaching and research institutions in France or abroad, or from public or private research centers.
L'archive ouverte pluridisciplinaire HAL, est destinée au dépôt et à la diffusion de documents scientifiques de niveau recherche, publiés ou non, émanant des établissements d'enseignement et de recherche français ou étrangers, des laboratoires publics ou privés. 


\title{
Perceptions of Self and Group in the Context of a Threatened National Identity: A Field Study
}

\author{
James E. Cameron \\ Saint Mary's University \\ Julie M. Duck and Deborah J. Terry \\ University of Queensland
}

\section{Richard N. Lalonde}

York University

\begin{abstract}
Previous research indicates that people who are highly identified with their groups tend to remain committed to them under threat. This study examines the generalizability of this effect to (a) a real-life context involving the perception that others view the ingroup (Australians) as intolerant of minorities and (b) various dimensions of social identification. The sample comprised 213 respondents to a random mail survey. Perceived threat was inversely related to self-stereotyping (i.e. perceptions of self-ingroup similarity), but only for individuals with weak subjective ties to other group members. Threat perceptions were also predictive of enhanced judgments of within-group variability on threat-relevant dimensions, particularly for individuals with weaker ingroup ties. Various strategies for coping with a threatened social identity are linked to different facets of social identification.
\end{abstract}

KEYWORDS self-stereotyping, social identification, threat

JUsT as people feel pride in the victories and accomplishments of their social groups (e.g. Cialdini et al., 1976; Wann \& Branscombe, 1990), they feel the sting and shame of the more ignominious moments of the collective (e.g. Doosje, Branscombe, Spears, \& Manstead, 1998). This highlights the importance of group membership in shaping self-conception and self-evaluation (Tajfel \& Turner, 1979). It is also true, however, that a given group will hold greater psychological significance for some members than for others, and there is abundant evidence that these highly identified individuals perceive and respond to group-relevant events in predictably different ways (e.g. Doosje \&

\footnotetext{
Author's note

Address correspondence to James E. Cameron, Department of Psychology, Saint Mary's University, Halifax, Nova Scotia, Canada B3H 3C3

[email: jim.cameron@smu.ca]
} 
Ellemers, 1997). In this study, we investigated the interactive effects of social identity and perceived threat with a focus on two central issues: (a) the type of strategy taken in response to threat, and (b) the particular aspects of social identification that moderate responses to threat.

\section{Social identity and threat}

Social identity theory (Tajfel, 1978; Tajfel \& Turner, 1979) assumes that people strive to maintain positive self-esteem. Because groups contribute not only to self-definition but also to self-evaluation, people's affiliation with and psychological attachment to their ingroups is one important way in which self-esteem is regulated. Tajfel and Turner (1979) specified a number of strategies available (depending on the nature and subjective judgments of the relevant intergroup context) to people with less-than-satisfactory social identities, ranging from individual behaviors such as dissociating oneself from or leaving the group, to collective strategies such as evaluating the ingroup in relatively positive terms on status-irrelevant dimensions or competing directly with a higher-status outgroup.

Threats to the content and value of group membership are distinguished in social identity theory (see also Breakwell, 1983), such that social identity may be threatened if the ingroup is compared to an outgroup that is highly similar or that challenges the ingroup's superiority on a relevant dimension (Tajfel, 1978; Turner \& Brown, 1978; van Knippenberg, 1989). More recently, Branscombe, Ellemers, Spears, and Doosje (1999) presented an elaborated taxonomy that indicates two distinct types of value threat: (a) threats to the competence of the group (e.g. issues of relative worth, performance, or status), and (b) threats to collective morality, which we examined in the present study.

Nations often fall under the shadow of the perceived immorality of their collective behavior. Sometimes group morality is impugned by how one nation treats another (e.g. during war, occupation, or colonization), but often perceptions of morality reflect how a country treats its own members, particularly those who are relatively powerless, stigmatized, or otherwise disenfranchised (e.g. members of visible minority groups). As Branscombe et al. (1999) noted, threats implicating morality are somewhat unique because their origin is not necessarily external (e.g. discrimination by outgroup members); rather, they often reflect the real or perceived actions of ingroup members themselves. Still, people are especially sensitive to criticism that comes from outside the group (Hornsey, Oppes, \& Svensson, 2002), so their perception of what others believe to be true is likely to be of some importance. In recent years such concerns have arisen among citizens of western democratic countries in which extreme right-wing political elements have achieved some measure of success, including Austria, France, and the Netherlands.

In this study, we focused on the threat perceived by some Australians following the success of the One Nation party in the state of Queensland. Led by erstwhile political independent Pauline Hanson, One Nation distinguished itself with a populist platform that called for reduced Asian immigration and an end to benefits for Aboriginal peoples and to multiculturalism. One particularly acute outcome of the initial success of One Nation, which received almost one-quarter of the vote in the Queensland state election of June 1998, ${ }^{1}$ was the concern that the international reputation of Australia was damaged by the racist sentiments associated with the party-a fear, in other words, that 'Australia became typecast abroad by Hanson' (P. Kelly, 1998, p. 95; see also Duck, Lalonde, \& Weiss, 2003; Kennedy, 1998). We addressed a number of ways in which people might respond to this threat, and the extent to which such responses are predictable as a function of the nature and strength of national identification.

\section{Responding to social identity threat}

A number of options are available to a group member with a threatened social identity. We focus on two strategies that correspond to our measured criteria: (a) distancing oneself from 
the group, and (b) altering perceptions of group variability.

\section{Perceptions of similarity between self and group: 'I'm not like them'}

According to social identity theory (Tajfel \& Turner, 1979), individuals may cope with a negative social identity by engaging in 'social mobility' strategies that involve a dissociation of self from the group (e.g. succeeding on one's own merits). Although these might sometimes entail concealing or disavowing group membership, such options are often neither possible nor desirable in the context of enduring reallife group memberships rooted in biology, culture, and/or demography. Alternatively, individuals can distance themselves from the group by perceiving themselves as different from other ingroup members ('I'm not like them'). One index of psychological distance between self and group is self-stereotyping; that is, the extent to which individuals perceive themselves in terms of group-defining attributes. This perception is important from the perspective of self-categorization theory (Turner, Hogg, Oakes, Reicher, \& Wetherell, 1987) because it corresponds to the 'depersonalization' of self-conception underlying group and intergroup behavior.

Self-stereotyping presents a number of possibilities with respect to maintaining a positive social identity or attenuating the psychological implications of a negative one. Simon, Pantaleo, and Mummendey (1995), for example, found that people tended to emphasize self-ingroup similarities on positive traits and selfingroup differences on negative traits. Accordingly, the need for positive self-esteem might lead to decreased levels of self-stereotyping when the ingroup's image is negative or when social identity is otherwise threatened. However, previous research has demonstrated that this tendency is moderated by an important variable: the strength of group identification. In a series of experiments in which threat to group status and distinctiveness was manipulated, Spears, Doosje, and Ellemers (1997) found not only that self-stereotyping was more evident for high identifiers than for low identifiers, but also that this was particularly apparent in high-threat conditions. Thus, whereas low identifiers tended to disassociate from the group (by viewing themselves as less similar to the group) if the collective position was rendered insecure in some way, high identifiers were likely to maintain or even enhance their level of selfstereotyping in the face of threat.

But if group members opt to remain psychologically committed to the group, then what can they do to repair their threatened identities? Previous work has pointed to a number of variously subtle and creative strategies, which relate to how the group is perceived by its members.

\section{Perceptions of variability: 'We're not all like that'}

One fairly direct response to social identity threat of the type we focus on in this studythat is, the perception that others believe the group to have a negative trait (intolerance)-is to deny or counter the implication ('We're not like that'). A strategy of denial, however, becomes tenuous when the source of the threat or the nature of the threatening information cannot be easily dismissed. An alternative and more subtle route to an enhanced personal or social identity involves emphasizing differences among group members ('We're not all like that'; Doosje, Spears, \& Koomen, 1995; Doosje et al., 1998; Lee \& Ottati, 1995). ${ }^{2}$ This has two potential consequences. First, the 'dilution' conferred by perceived heterogeneity allows individuals to avoid any implication that such negative information applies to them (Doosje, Ellemers, \& Spears, 1995; Doosje, Spears, \& Koomen, 1995). Thus, it has been suggested that emphasizing group heterogeneity is an individualistic strategy that puts psychological distance between the self and the group (Doosje, Ellemers, \& Spears, 1995). This is consistent with evidence that perceptions of group heterogeneity increase for low identifiers when group membership is threatened (Doosje, Ellemers, \& Spears, 1995), and the accompanying notion that low identifiers are apt to let the group 'fall apart' (Doosje \& Ellemers, 1997) when it is challenged in some way. Alternatively, 
exaggerating ingroup variability can function in certain contexts as a collective strategy, as opposed to a self-serving one, by downplaying the extent to which ingroup members share a negative trait (Doosje, Spears, \& Koomen, 1995). This interpretation is consistent with Doosje et al.'s (1998) finding that high (and not low) identifiers perceived more withingroup variability when they were given ambiguous information referring to their nation's historically negative treatment of another country. Finally, there is additional evidence (Lee \& Ottati, 1995) that the protection of social identity via perceptions of variability does not necessarily occur in a global fashion, but rather varies according to the relationship of specific traits to the nature of the threat. The 'variability strategy' (Doosje, Spears, \& Koomen, 1995), for example, is likely to be particularly effective when ingroup heterogeneity is highlighted along dimensions that are specifically relevant to the threat (e.g. 'We're not all prejudiced').

Thus, emphasizing differences within the group can serve to protect against threat in one of two ways: it can allow low identifiers to 'save themselves' by diluting the personal implications of the threatening information (an individualistic strategy akin to decreased selfstereotyping), and it can allow high identifiers to 'save the group' by protecting the image of the group as a whole (a collective strategy). These two routes to a more positive personal or social identity imply different expectations about who will respond to threat, and in what way(s), and it is one of the aims of the present study to address this issue.

\section{Rationale for this study}

In summary, previous experimental research indicates some consistent patterns with respect to responses to threatened social identity: low identifiers tend to disassociate from the group, whereas high identifiers are more likely to 'stick together' and engage in collective responses when the group is threatened (Doosje \& Ellemers, 1997; Ellemers, Spears, \& Doosje, 1997; Spears et al., 1997). There remain, however, a number of points of ambiguity. First, whereas most prior research has the advantage of experimental manipulations of threat (and sometimes social identification; e.g. Ellemers et al., 1997) that enable the establishment of cause and effect relations between threat, identity, and various outcomes, the extent to which such relationships generalize to naturalistic threats to social identity-where such threats are likely to be more fluid and diffuse than in laboratory contexts-is unclear. Second, threats involving the perceived immorality of the group have received much less research attention than threats associated with collective incompetence. It is therefore of interest to further investigate whether people respond to different threats to the value of social identity in similar ways. Third, Spears et al. (1997) suggested that self-stereotyping and perceptions of variability function as parallel identity management strategies (i.e. that decreased self-stereotyping and exaggerated intragroup variability both reflect attempts to distance the self from the group when social identity is threatened) but apparently no study has investigated both responses simultaneously. Moreover, there is some indication, as noted above, that enhanced perceptions of ingroup variability can also serve collective motivations that arise from a need for positive social identity (Doosje et al., 1998). To date, then, it is not entirely clear when high identifiers will tend to enhance the variability as opposed to the homogeneity of the ingroup.

A final issue that defines our present approach concerns the nature of social identity itself. Specifically, while previous research on responses to group-related threat has highlighted the importance of social identification as a moderator variable (Doosje \& Ellemers, 1997; Spears et al., 1997; Spears, Doosje, \& Ellemers, 1999), it has operationalized the latter variable in unidimensional terms. Although this is typical in social identity research, recent work has indicated that a multifactor conception of social identification may be more appropriate (Cameron, 2004; Cameron \& Lalonde, 2001; Deaux, 1996; Ellemers, Kortekaas, \& Ouwerkerk, 1999; 
Jackson, 2002; Jackson \& Smith, 1999). Given this, we suggest that distinguishing between specific facets of national identification will enhance the prediction of responses to social identity threat.

\section{Three factors of social identity}

Although various multidimensional models of social identification have been proposed, there appears to be some convergence between at least three recent measures (Cameron, 2004; Ellemers et al., 1999; Jackson, 2002), each of which specifies three factors and makes some distinction between cognitive, evaluative, and emotional facets (cf. Tajfel, 1978). One of these models (Cameron, 2004) has been systematically validated across a number of social groups, and specifies the following components: (a) centrality, which reflects the prominence of the group in self-conception and thought, (b) ingroup ties, or the perceived bond and belongingness that individuals feel with other group members, and (c) ingroup affect, which reflects the positivity of feelings derived from group membership, and which is conceptually similar to private collective self-esteem (Luhtanen \& Crocker, 1992).

One advantage of measurement of social identification along multiple dimensions is that various group-relevant beliefs and behaviors may be specifically predicted by one or more of its facets (e.g. Cameron, 2001; Cameron \& Lalonde, 2001; Ellemers et al., 1999; Jackson, 2002). We expected such specificity in the present case for two reasons. First, given the affective nature of threat, we anticipated that correspondingly emotional aspects of social identification would be implicated. Second, and more specifically, if ingroup ties reflect individual-level perceptions of group cohesion, or the extent to which people perceive themselves to be 'stuck to' their group (cf. Bollen \& Hoyle, 1990), then this dimension of social identity should be particularly important in predicting who is likely to 'stick with' their group (cf. Ellemers et al., 1997) when it is challenged. In other words, we propose that the 'die-hard' group members (cf. Wann \& Branscombe, 1990) can be characterized specifically in terms of their strong subjective ties to others in the group, whereas 'fair-weather' group members will likely untie their already loose bonds to the group when it is threatened.

\section{Hypotheses}

To summarize, the rationale for this study is twofold: (a) to examine interactions between social identification and naturalistic threatthe fear that one's nation is perceived to condone prejudice-with respect to two strategies of identity management (selfstereotyping and perceptions of group variability), and (b) to determine the specificity of threat-related effects vis-a-vis particular aspects of social identity. Finally, unlike most previous studies of reactions to social identity threat, in which self-stereotyping or perceptions of variability were assessed in global terms (e.g. Spears et al., 1997), we examined responses as they occurred with respect to several dimensions: (a) positive ingroup stereotypic traits, (b) positive nonstereotypic traits, and (c) threatspecific attributes (e.g. intolerant). This allowed us to assess both the generality and specificity of identity management strategies across various ingroup and threat-relevant dimensions.

We expected, first, overall effects of social identification and threat, such that selfstereotyping would tend to be positively associated with national identification and negatively associated with perceived threat. Second, we hypothesized that threat would be inversely related to self-stereotyping particularly for low identifiers, consistent with the notion that lowidentifiers are apt to distance themselves (thereby 'saving themselves') from a threatened collective (Spears et al., 1997). Third, if different responses to threat by low identifiers and high identifiers reflect different levels of group commitment (Doosje, Ellemers, \& Spears, 1999), then the ingroup ties component of social identity should be the key moderator of the threat effect.

Joint effects of perceived threat and social identity were also anticipated for perceptions of intragroup variability, although previous research is more equivocal here with respect to 
the responses of low versus high identifiers. Given prior evidence (Doosje et al., 1998) that perceiving intragroup heterogeneity is one way to 'save the group' in the face of threats involving its (im)moral character, we expected this strategy to be employed by group members with strong subjective ties to their nation, and specifically along threat-relevant dimensions (e.g. intolerant).

\section{Method}

\section{Participants and procedure}

A random selection of potential respondents was drawn from the 1996 Queensland electoral role for three electoral divisions in Queensland (Brisbane, Capricornia, and Maranoa). Questionnaires (followed by reminder cards) were mailed in July 1998 to 940 residents, and 425 $(45 \%)$ were returned. Of these, 253 were returned completed, 133 were returned from incorrect addresses, and 39 were returned unanswered. Thus, the response rate for correctly addressed questionnaires was $31.4 \%$. The sample comprised 127 from Brisbane, 91 from Capricornia, and 21 from Maranoa. Response rates did not differ across electoral districts $\left(\chi^{2}(2)=4.32, n s\right)$. Respondents were 128 women and 125 men ranging in age from 18 to 85 years $($ mean age $=48.5)$. For the purposes of this study we focused our analyses on the majority $(N=213 ; 107$ women and 106 men) who indicated that they were White and born in Australia. $^{3}$

\section{Measures}

Variables were assessed in the following order: (a) social identification, (b) perceptions of threat, and (c) self-stereotyping and perceptions of intragroup variability.

Social identification Three dimensions of social identification were assessed using a 12-item scale tapping the following facets: (a) centrality (e.g. 'I often think about the fact that I am an Australian'; $\alpha=.67$ ), (b) ingroup ties (e.g. 'In a group of Australians, I really feel that I belong'; $\alpha=.71$ ), and (c) ingroup affect (e.g. 'In general, I'm glad to be an Australian'; $\alpha=$
.80). The three factors have been reliably assessed and distinguished across a variety of social groups, including gender, ethnicity, and nationality (e.g. Cameron \& Lalonde, 2001; Lalonde, 2002), and confirmatory factor analyses indicate that the three-factor model performs better than one- or two-factor alternatives in the present data set and several others (Cameron, 2004). Responses were made on 7-point Likert scales $(1=$ strongly disagree, $7=$ strongly agree) and were averaged such that higher scores reflect stronger social identification.

Threat perceptions We operationalized threat perceptions in terms of a subjective concern or worry that people in other countries perceive Australians to be intolerant of ethnic and racial diversity. Four items were developed to assess this, with two referring directly to Pauline Hanson, then leader of the One Nation party: 'In light of the Pauline Hanson affair, how concerned are you that people from other countries have developed a more negative view of Australia and our racial and ethnic relations?' $(1=$ not at all concerned $; 7=$ very concerned $)$, 'How worried are you that others perceive Australians to be intolerant of minority groups?' $(1=$ not at all worried $; 7=$ very worried $)$, 'How concerned are you that people from other countries may have developed more negative views of Australians' racial attitudes in recent years?' ( 1 = not at all concerned; 7 = very concerned), and 'How concerned are you that people in other countries will think that Pauline Hanson's views reflect those of the majority of Australians?' ( 1 = not at all concerned; $7=$ very concerned $)$. Averaging responses to these items resulted in a scale with a high degree of internal consistency $(\alpha=.96)$.

Perceptions of self and group A number of scales were used to assess perceptions of self and ingroup. The Australian ingroup stereotype was represented by three positive adjectives (happygo-lucky, easygoing, and sportsmanlike) used in previous research (Haslam, Oakes, McGarty, \& Turner, 1996; Kippax \& Brigden, 1977). We also selected three positive traits (sophisticated, 
Table 1. Correlations between predictor and criterion variables

\begin{tabular}{|c|c|c|c|c|c|c|}
\hline \multirow[b]{2}{*}{ Criterion variables } & \multirow[b]{2}{*}{$M$} & \multirow[b]{2}{*}{$S D$} & \multicolumn{4}{|c|}{ Predictor Variables } \\
\hline & & & Ingroup ties & Ingroup affect & Centrality & Threat \\
\hline \multicolumn{7}{|l|}{ Self-stereotyping } \\
\hline Stereotypic traits & 5.19 & 1.11 & $.27^{* *}$ & $.23^{* *}$ & .11 & $-.19^{* *}$ \\
\hline Nonstereotypic traits & 4.38 & 1.33 & $.28^{* *}$ & $.37^{* * *}$ & .05 & $-.23^{* *}$ \\
\hline 'Accepting of others' & 4.76 & 1.89 & $.33^{* *}$ & $.19^{* *}$ & .06 & $-.21^{* *}$ \\
\hline 'Intolerant' & 4.12 & 1.89 & $.18^{* *}$ & .16 & .04 & $-.34^{* *}$ \\
\hline \multicolumn{7}{|l|}{ Perceptions of similarity } \\
\hline Stereotypic traits & 5.31 & 0.98 & $.15^{*}$ & $.17^{*}$ & $.16^{*}$ & -.09 \\
\hline Nonstereotypic traits & 4.63 & 1.07 & .13 & .09 & .07 & -.12 \\
\hline 'Accepting of others' & 4.84 & 1.41 & .08 & .05 & .00 & $-.14^{*}$ \\
\hline 'Intolerant' & 4.49 & 1.45 & .09 & .02 & -.04 & -.13 \\
\hline
\end{tabular}

${ }^{*} p<.05 ;{ }^{* *} p<.01$.

conscientious, and intellectual) to capture perceptions along a nonstereotypic dimension (i.e. not sophisticated, not conscientious, and not intellectual are consistent with the Australian ingroup stereotype). However, given positive, moderate correlations between self-stereotyping on stereotypic and nonstereotypic traits, we treated the nonstereotypic (i.e. 'not us') dimension separately in analyses. Finally, we included two attributes (intolerant and accepting of others) that were more directly relevant to the nature of the threat. Self-stereotyping was operationalized in terms of judgments of selfingroup similarity (cf. Simon et al., 1995; Spears et al., 1997) on each item (i.e. 'How similar are you to other Australians on this characteristic?' where $1=$ not at all similar and $7=$ very similar ). Perceptions of variability were assessed for each item by asking 'How similar are Australians to each other on this characteristic?' (cf. Doosje, Ellemers, \& Spears, 1995; response options ranged from $1=$ not at all similar to $7=$ very similar). Internal consistencies were acceptable for the ingroup stereotype measures $(\alpha=.63$ for self-stereotyping and .72 for perceptions of variability) and for the nonstereotypic traits (both $\alpha$ $=.70$ ). Ratings on the two threat-relevant dimensions, however, were less strongly associated with each other $(r=.41$ for self-stereotyping and $r=.31$ for perceptions of variability). For this reason, the two threat-relevant items were treated separately in analyses.

\section{Results}

\section{Correlations between variables}

Australian national identification was, on average, strong and positive- $M \mathrm{~s}$ (and $S D \mathrm{~s}$ ) for ingroup ties, ingroup affect, and centrality were 5.56 (1.06), 6.28 (0.86), and 4.55 (1.12) respectively-and the mean response to the threat items was $4.41(S D=2.12)$, providing some indication that concerns regarding a tainted national image were subjectively real for the respondents. Correlations between the predictor variables (ingroup ties, ingroup affect, centrality, and perceived threat) and criterion variables (self-stereotyping and perceptions of variability along the stereotypic, nonstereotypic, and threat-specific dimensions) are shown in Table 1. Consistent with hypotheses, social identification tended to be accompanied by the perception that the self is similar to other ingroup members; this was true, however, only for ingroup ties and ingroup affect. The social identity components were largely unrelated to perceptions of variability within the group, although all three facets of identification were reliably and positively associated with perceptions of ingroup homogeneity on stereotypic 
traits. The perception of threat was associated with opposite trends. In line with the notion that a negative group image leads people to distance themselves from the collective, threat was consistently and negatively associated with self-stereotyping. Subjective threat was also associated with a relatively heterogeneous view of the ingroup, although this was significant only for 'accepting of others'. Although these correlational patterns were generally consistent with expectations, our focal hypotheses concerned the unique effects of the various aspects of social identification, and, more important, the joint effects of identification and threat. We tested these in the regression analyses reported below.

\section{Overview of regression analyses}

A series of eight hierarchical regression analyses was conducted, with self-stereotyping and perceptions of variability as criterion variables, and with each of these assessed in terms of ingroup stereotypic traits, nonstereotypic traits, and the two threat-relevant traits. ${ }^{4}$ Following procedures described by Aiken and West (1991), the predictor variables-perceived threat, centrality, ingroup ties, and ingroup affect-were centered and entered at Step 1 of the regressions. Two-way interactions involving threat and the three components of social identification were tested hierarchically (see Cohen \& Cohen, 1983) at Step 2. Unstandardized regression coefficients are reported throughout, given their interpretability in the context of interaction effects (Aiken \& West, 1991). Significant effects are accompanied by squared semipartial correlations $\left(s r^{2}\right)$ as estimates of effect size.

\section{Predicting self-stereotyping}

The regression equation predicting self-stereotyping on positive, ingroup defining traits was significant at Step $1(F(4,203)=6.27, p<.001$, $R^{2}=.11$ ). Two effects were reliable: perceptions of self-ingroup similarity were positively associated with the ingroup ties component of social identity $\left(\beta=.24 ; t(203)=2.65, p=.009, s r^{2}=\right.$ $.03)$, and negatively associated with perceived threat $\left(\beta=-.09 ; t(203)=-2.49, p=.01, s r^{2}=\right.$
.03). The interactions added at Step 2 between threat and the three factors of social identity did not, as a group, contribute significantly to prediction $\left(F(7,200)=4.31, p<.001, R^{2}=.13\right.$, $\left.\Delta R^{2}=.02\right)$, but the anticipated Threat $\times$ Ingroup Ties interaction was significant $(\beta=$ $\left..09 ; t(200)=2.18, p=.03, s r^{2}=.02\right)$. The interaction is depicted in Figure 1, with predicted values plotted at \pm 1 standard deviation from the means of each variable. As anticipated, the tendency to psychologically distance the self from the group when threatened was moderated by social identification; simple slope analyses indicated that the negative association between threat and self-stereotyping was significant for people with weak ingroup ties $(\beta=$ $-.18 ; t(200)=-3.18, p<.01)$, whereas people with a strong subjective bond to their group tended to self-stereotype even when they perceived the group's image to be threatened ( $\beta=$ $.02 ; t(200)=.25, n s)$.

The regression predicting self-stereotyping in terms of nonstereotypic traits was also significant at Step $1(F(4,201)=12.66, p<.001$, $\left.R^{2}=.20\right)$. Aspects of social identification were significant predictors of perceptions of selfingroup similarity on this dimension; although the effect of ingroup ties was not reliable $(\beta=$ $.19 ; t(201)=1.78, p=.08)$, ingroup affect was positively associated with self-stereotyping ( $\beta=$ $\left..51 ; t(201)=3.93, p<.001, s r^{2}=.06\right)$, and centrality was a negative predictor $(\beta=-.21 ; t(201)$ $\left.=-2.44, p=.015, s r^{2}=.02\right)$. Consistent with expectations, perceived threat was associated with attenuated self-stereotyping $(\beta=-.11$; $\left.t(201)=-3.00, p=.003, s r^{2}=.04\right)$. Two significant interactions at Step 2 reliably contributed to prediction $(p<.05)$, however, and indicated again that the effect of threat was moderated by social identification $(F(7,198)=8.67, p<$ $\left..001, R^{2}=.23, \Delta R^{2}=.03\right)$. The first was the expected Threat $\times$ Ingroup Ties effect, which assumed the same form as previously (Figure 1 ) $\left(\beta=.12 ; t(198)=2.59, p=.01, s r^{2}=.03\right)$. Simple slope analyses confirmed that the effect of threat was significant and negative for individuals with relatively weak ingroup ties $(\beta=$ $-.23 ; t(198)=-3.67, p<.01)$, whereas the slope of the simple regression line was not 


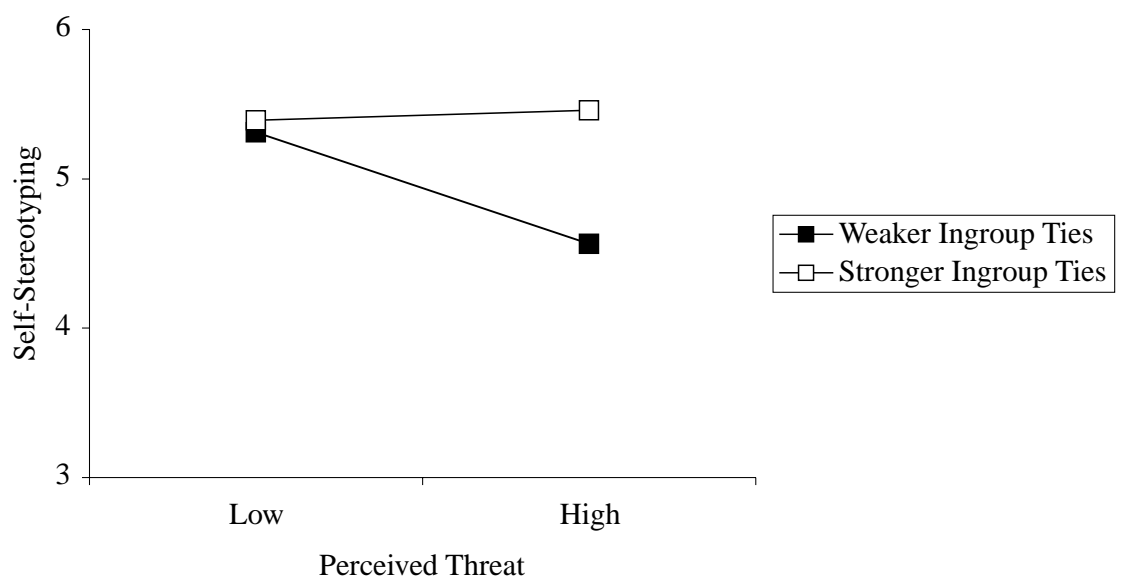

Figure 1. Predicted levels of self-stereotyping on ingroup stereotypic traits, plotted at \pm 1 standard deviation of perceived threat and ingroup ties.

significantly different from zero for people with stronger ingroup ties $(\beta=.07 ; t(198)=.54$, $n s)$. The second significant interaction involved perceived threat and ingroup affect $\left(\beta=-.16 ; t(198)=-2.38, p=.018, s r^{2}=.02\right)$. As seen in Figure 2, this indicates a different and unexpected pattern: the inverse association between threat and self-stereotyping was significant for those with a positive affective attachment to the group $(\beta=-.24 ; t(198)=$ $-3.93, p<.01)$, but nonsignificant for those with less positive levels of ingroup derived affect $(\beta=.02, t(198)=.31, n s)$.

Regressions involving self-stereotyping in terms of the two threat-specific traits-intolerant $\left(F(4,197)=8.93, p<.001, R^{2}=.15\right)$, and accepting of others $(F(4,201)=9.48, p<.001$, $R^{2}=.16$ )—indicated similar effects at Step 1. In each case, self-stereotyping was positively associated with ingroup ties $(\beta=.31 ; t(197)=1.99, p$ $=.048, s r^{2}=.02$, and $\beta=.70 ; t(201)=4.54, p<$ $.001, s r^{2}=.09$, respectively), and negatively associated with perceived threat $(\beta=-.30$; $t(197)=-5.09, p<.001, s r^{2}=.11 ;$ and $\beta=-.18$; $t(201)=-3.03, p=.003, s r^{2}=.04$, respectively). In neither case, however, was any interaction significant at Step 2.

\section{Predicting perceptions of variability}

A second set of hierarchical regressions was conducted to analyze perceptions of ingroup variability. Although our hypotheses regarding perceived variability centered on the threatspecific attributes, we also conducted parallel analyses on the stereotypic and nonstereotypic dimensions. Collectively, the predictor variables did not significantly account for perceptions of variability on the ingroup stereotype $(F(4,201)$ $\left.=2.38, p=.053, R^{2}=.05\right)$, and no single effect was reliable. Adding the interactions at Step 2 did not improve prediction $(F(7,198)=1.72, p$ $\left.=.11, R^{2}=.06, \Delta R^{2}=.01\right)$. The regression equations predicting perceptions of variability on nonstereotypic traits also were not significant at Step $1\left(F(4,200)=1.78, p=.13, R^{2}=.03\right)$, or Step $2\left(F(7,197)=1.28, p=.26, R^{2}=.04, \Delta R^{2}\right.$ $=.01)$, and again there were no reliable effects.

For ratings of intragroup variability on the 'intolerant' dimension, Step 1 of the regression was not significant $\left(F(4,197)=1.48, p=.21, R^{2}\right.$ $=.03)$. There was some indication that perceived threat was associated with judgments of less within-group homogeneity, but the effect was nonsignificant $(\beta=-.08 ; t(197)=-1.74, p=$ $.08)$. Moreover, adding the interactions at Step 2 provided no evidence that emphasizing heterogeneity in response to threat was any more 


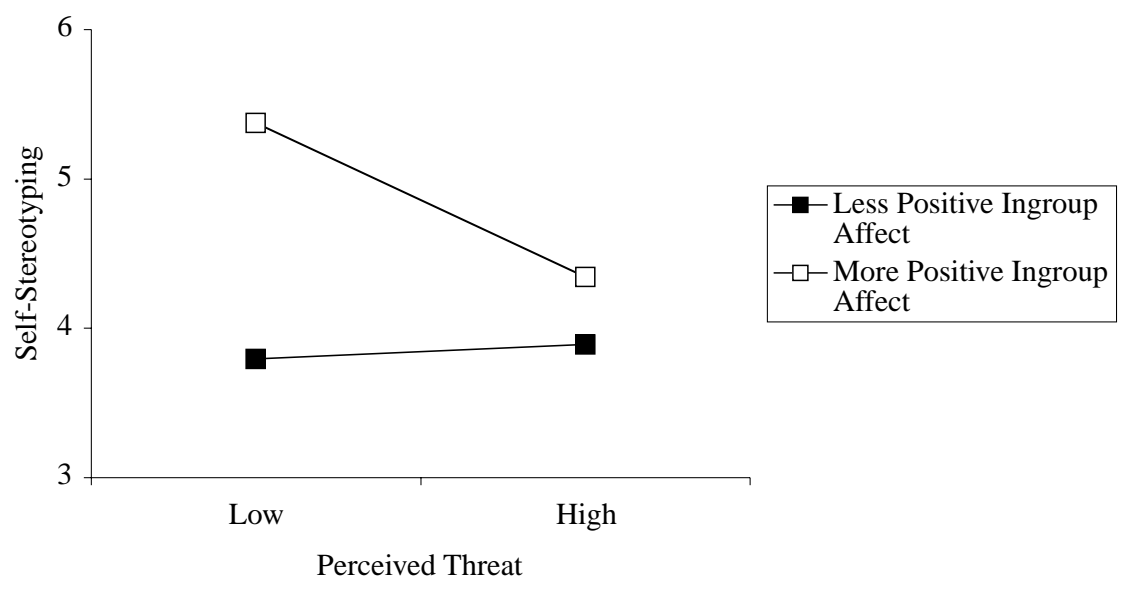

Figure 2. Predicted levels of self-stereotyping on nonstereotypic traits, plotted at \pm 1 standard deviation of perceived threat and ingroup affect.

likely for high identifiers than for low identifiers $\left(F(7,194)=0.96, p=.46, R^{2}=.03, \Delta R^{2}=\right.$ $.00)$.

The regression involving the perceived variability of the ingroup on the accepting of others' dimension indicated the expected effect of threat $(\beta=-.09 ; t(200)=-1.98, p=$ $\left..048, s r^{2}=.02\right)$, although the overall equation was nonsignificant $\left(F(4,200)=1.41, p=.23, R^{2}\right.$ $=.03)$. At Step 2, although the combined interaction effects did not make a reliable contribution to prediction $(F(7,197)=1.63, p=.13$, $\left.R^{2}=.05, \Delta R^{2}=.02\right)$, the Threat $\times$ Ingroup Ties interaction was significant $(\beta=.12 ; t(197)=$ 2.18, $\left.p=.03, s r^{2}=.02\right)$. As shown in Figure 3, this reflects the (unexpected) tendency for the negative effect of threat to be manifested for those with relatively weak ties to the group. Analysis of the simple slopes indicated that under social identity threat, those with relatively strong ingroup ties were most likely to maintain a fairly homogeneous view of the ingroup $(\beta=.04 ; t(197)=.63, n s)$, whereas those with weaker ingroup ties tended to perceive more within-group differences on the threat-relevant dimension $(\beta=-.22 ; t(197)=$ $-2.46, p<.01)$.

\section{Discussion}

There is accumulating evidence that people respond to threats to social identity in creative and flexible ways, and that the nature of such responses reflects the strength of their social identification: high identifiers tend to defend and 'stick with' their group when it is challenged, whereas low identifiers are more likely to distance themselves from a threatened group (e.g. Doosje \& Ellemers, 1997; Ellemers et al., 1997; Spears et al., 1997). In this study, we investigated the generalizability and specificity of this pattern in the context of naturalistic threat to national (Australian) identity, and in terms of two types of perceptions: that of similarity between the self and other group members (self-stereotyping) and that of similarity between ingroup members as a whole (within-group variability). We were also interested in the particular aspects of social identification that moderate responses to threatwhat, in other words, is the precise nature of the psychological 'glue' that binds high identifiers to the group?

\section{Joint effects of social identification and threat} Analyses of self-stereotyping patterns provided qualified support for our expectations regarding 


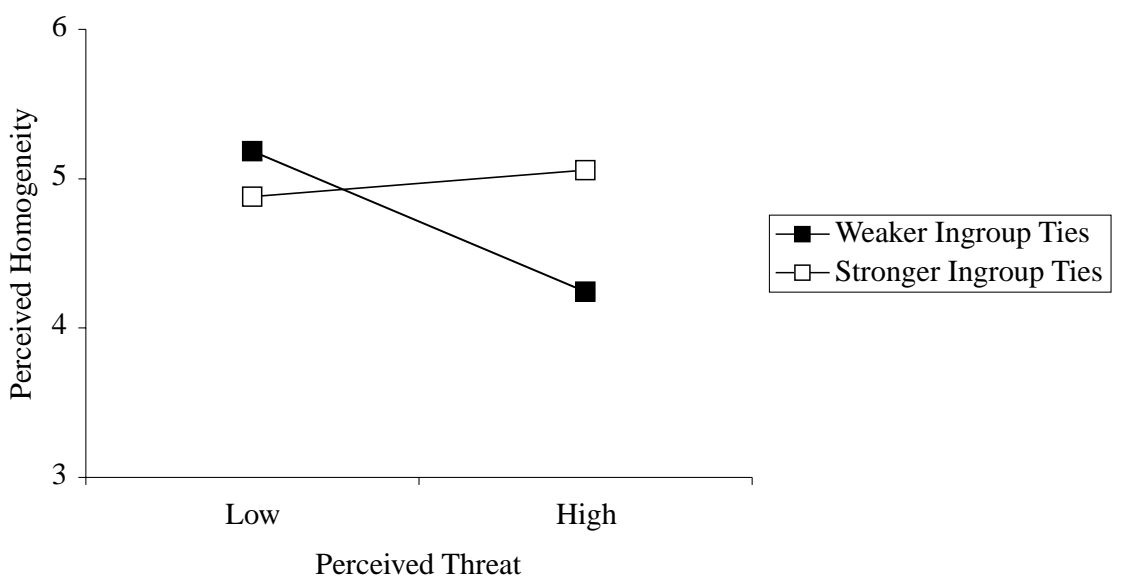

Figure 3. Predicted levels of perceived within-group similarity, plotted at \pm 1 standard deviation of perceived threat and ingroup ties.

overall effects of identification and perceived threat, and the moderating role of particular facets of identification. In accordance with theories of social identity and selfcategorization (Tajfel \& Turner, 1979; Turner et al., 1987), psychological attachment to the group was associated with the perception that the self is similar to other group members. The findings extend previous research (Spears et al., 1997), however, by demonstrating that this was particularly true for one element of social identification: subjective ties between the self and other group members. Regression analyses in which three components of identification were entered simultaneously indicated that ingroup ties were significantly associated with self-stereotyping for all dependent measures with the exception of nonstereotypic traits. The specificity of these effects is brought into relief by the finding that centrality-the cognitive aspect of social identification-was inversely predictive of self-stereotyping on the nonstereotypic traits. This suggests that the cognitive prominence and importance of national identity is associated with maintaining the distinctiveness of the group, which could entail eschewing 'not-us' aspects of the self, even if they are favorable. However, ingroup affect was a significant positive predictor of self-stereotyping on the nonstereotypic dimension, suggesting that aligning views of self with the group on positive traits could serve selfesteem needs, even if the traits are not ingroup-defining.

The link between self-esteem and group membership is fundamental to social identity theory, as is the expectation that people will shift their group-related perception and/or behavior as a means of self-esteem maintenance or repair. Thus, we hypothesized that a perceived threat to the image of the group would be associated with a general tendency to psychologically distance the self from other group members. Indeed, the effect of threat was consistent across dependent variables: the more people feared that the ingroup's image was tainted by implications of intolerance, the less like other Australians they perceived themselves to be. More important, however, the regression analyses indicated that the tendency for self-stereotyping to be attenuated in the presence of threat was moderated by social identification. There was evidence of two types of moderation. The first was consistent with our expectation that threat would engender decreased self-stereotyping for low identifiers, 
and particularly those with relatively weak subjective ties to other group members, whereas members with strong ingroup ties would maintain their psychological closeness to the group. This finding, which occurred on stereotypic and nonstereotypic dimensions of selfingroup similarity, replicates the pattern Spears et al. (1997) obtained following their experimental manipulations of threats to group status and distinctiveness.

The second way in which the effect of threat was moderated by social identification took place only on the nonstereotypic dimension and involved ingroup affect (i.e. the evaluative component of identification). This interaction was opposite to that of the hypothesized pattern in that threat was inversely related to selfstereotyping for individuals with more positive group-derived feelings, whereas individuals with less positive ingroup affect had similar (though somewhat lower) levels of self-stereotyping regardless of perceived threat. What accounts for this unexpected pattern? One possibility, which arises from the distinction between ingroup ties and ingroup affect as separable facets of social identity, is that they reflect different qualities of attachment to the group. Analogous to the distinction between 'die-hard' and 'fair-weather' group members (see Wann \& Branscombe, 1990), whereas strong ingroup ties ensure 'sticking with' the group regardless of changes in its evaluation, affective attachment might provide a basis for psychological closeness to the group only when conditions are favorable. Thus, 'fair-weather' group members who are invested in the collective primarily to the extent that it enhances selfesteem might distance themselves from their compatriots when it no longer serves that function.

Reduced self-stereotyping is one way to cope with a threatened social identity; the second strategy we focused on in this study concerned perceptions of variability. Given Doosje et al.'s (1998) evidence that high identifiers tended to perceive the ingroup as relatively heterogeneous when group morality was threatened, we hypothesized that a general tendency to emphasize within-group differences in the face of threat (e.g. 'We're not all prejudiced') would be evident particularly for individuals who felt strong ties to their nation. Regression analyses testing the unique effects of the three factors of national identification provided partial support for the specificity of this effect in that it occurred on a threat-relevant dimension ('accepting of others') and involved ingroup ties, but the nature of the interaction was not anticipated. Perceptions of the similarity of group members were inversely associated with threat only for people with relatively weak ingroup ties, with an opposite (though nonsignificant) trend for individuals with stronger ties to the group. However, the effect is similar to the results of other research (Doosje, Ellemers, \& Spears, 1995) showing that social identity threat (i.e. low group status) led low identifiers to perceive the ingroup as relatively heterogeneous, whereas the converse was true for high identifiers. In this light, a plausible interpretation of the present results is that individuals with weak ties to their compatriots were inclined to let the group 'fall apart' when its image was threatened (Ellemers et al., 1997), while more strongly identified individuals maintained a view of ingroup members as relatively homogeneous in terms of their tolerance.

\section{Qualifications and implications}

The results should be interpreted with a number of caveats in mind. First, the magnitudes of the key interaction effects were quite small. Although this is perhaps unsurprising given the field context of the study, and although it is counterbalanced by the consistency of the Threat $\times$ Ingroup Ties effect across measures and with other research, the unanticipated Threat $\times$ Ingroup Affect interaction should be interpreted cautiously. Second, our measurement of responses along threatspecific dimensions-which limited our evaluation of hypotheses regarding perceptions of variability to two single items-was less than ideal. Third, we acknowledge the possibility that individuals who chose to complete and return surveys differed from their nonresponding counterparts, such that the former group, for example, might have been 
especially reactive to national identity threat and/or the social and political issues it involves. Finally, the correlational nature of the data does not allow us to discount various causal and dynamic linkages among variables. Consider, for example, the Threat $\times$ Ingroup Affect interaction, which we account for in terms of joint effects of perceived threat and social identification on self-stereotyping. Alternatively, it is possible that the alignment of self with the ingroup stereotype enhances the positive affective tone of national identity. Similarly, although social identification is treated here as a relatively enduring quality of individuals (see Cameron, 2004), this does not preclude its momentary responsiveness to contextual demands, such that attachment to the group may itself rise and fall as threat waxes and wanes (cf. Turner et al., 1987).

Nevertheless, the data demonstrate the generalizability of the moderating effect of social identification to a field setting and to a type of threat that captures the collective experience of a number of nations that have recently struggled with the image-damaging implications of political successes on the far-right wing. They also have several implications for research and theory in which social identification assumes a central role. First, the data strengthen the message of several recent studies (e.g. Cameron, 2001; Ellemers et al., 1999; Jackson, 2002) that the use of multidimensional measures of social identity lends nuance to the prediction of group-relevant perception and behavior. For example, effects of perceived threat were moderated only by the emotional facets of social identification (i.e. feelings of belonging and affect derived from group membership), which reflects the affective character of the threat experience. Even more specifically, however, and consistent with Doosje et al.'s (1999) conceptual equation of group commitment and ingroup identification-they defined the latter as 'the extent to which individuals feel strong ties with their group' (p. 85)—ingroup ties appear to be aptly described as 'the ties that bind' high identifiers to the group in times of crisis. On the other hand, the evaluative (or affective) facet of psychological attachment to the group, which features prominently in many operationalizations of social identification, was associated with independent and sometimes opposite effects (see also Cameron, 2001).

If social identity can be represented in terms of separable components, then a related implication is that various facets reflect different social psychological motivations (e.g. Deaux, 1996; Deaux, Reid, Mizrahi, \& Cotting, 1999; Hogg \& Abrams, 1990). In the present case, we speculate that distinctions between 'fairweather' and 'die-hard' group members (Wann \& Branscombe, 1990) can be informed by this perspective, such that they differ not simply in the strength of identification, but in its quality. Thus, for example, whereas the 'die-hards' are bound by ties to other group members, thus making their attachment to the group more grounded in relationships and less susceptible to fluctuations in the content or evaluation of social identity, the capriciousness of 'fairweather' group members might reflect their more shallow investment in the 'feel good', or self-esteem-serving aspect of group membership. Further research will be necessary to test this, and to pursue other ways in which social identity form maps onto social identity function.

The finding that ingroup ties moderate the effect of threat on self-stereotyping merges with previous work to provide a coherent account of the consequences of commitment to the group (e.g. Spears et al., 1999). The picture is somewhat more ambiguous, however, with respect to what Doosje, Spears, and Koomen (1995) referred to as the 'variability strategy'; that is, coping with a threatened social identity by emphasizing heterogeneity within the group. The present findings support Spears et al.'s (1997) suggestion that perceiving the self as different from the group and perceiving group members as different from each other can be parallel ways that individuals with weak ingroup ties manage social identity threat. However, inconsistent findings in previous work suggest that there are contextual factors that play a role in determining the efficacy of the variability strategy. Doosje et al. (1998) suggested that different responses reflect different stages in a 
group's course of action in the time frame surrounding the threat. When the threat is ongoing, maintaining or enhancing a cohesive view of the ingroup positions group members to take defensive (or offensive) action. In contrast, a threat that stems from past events (e.g. immoral behavior by ingroup members) does not demand the same immediacy of action, and emphasizing within-group variability facilitates a 'dilution' of the group's negative image (Doosje et al., 1998). This interpretation is consistent with the discrepancy between our results and those of Doosje et al. (1998), considering that we assessed perceptions of threat pertaining to the contemporary image and behavior of the group.

In conclusion, although social group membership confers a number of psychological benefits on individuals, it sometimes carries liabilities. This study adds to our understanding of the psychological correlates of group-related image problems in a real-world context, and converges with experimental evidence in delineating the various ways that people deal with a threatened social identity. If these patterns are generalizable, however, they are also specific, with respect to various dimensions of comparison and different facets of attachment to the group. 'Sticking with' one's compatriots is a matter not just of the strength of social identification, but also of its structure.

\section{Notes}

1. Since then, One Nation has virtually disappeared as a political entity, although what has become referred to as Hansonism (e.g. Manne, 1998) continues to be a relevant phenomenon in the Australian social and political climate.

2. When the group's competence (as opposed to its morality) is challenged, an opposite responseemphasizing intragroup homogeneity-may serve to enhance ingroup cohesion and to consolidate the group in response to intergroup competition (Branscombe et al., 1999; Doosje, Ellemers, \& Spears, 1995; Ellemers et al., 1997; C. Kelly, 1989; Rothgerber, 1997; Simon \& Brown, 1987; Turner, Hogg, Oakes, \& Smith, 1984).

3. Considering that the type of threat we tapped concerns perceptions of the treatment of
Aboriginals and immigrants in Australia, we reasoned (a) that White Australians would be most implicated, (b) that such a threat would potentially hold very different meanings for members of visible minority groups, and (c) that foreign-born residents would have a psychological 'way out' with a threat specific to Australian national identity.

4. Given the operational similarity of selfstereotyping and perceptions of variability (i.e. perceptions of self-ingroup similarity versus perceptions of similarity between ingroup members), a principal components analysis was conducted on the eight criterion variables of interest. Two factors had eigenvalues greater than 1.00 , accounting for $58.4 \%$ of the variance. Inspection of the obliquely rotated factors indicated that the first reflected perceptions of intragroup variability and the second reflected the four indexes of self-stereotyping.

\section{Acknowledgements}

A University of Queensland Postdoctoral Research Fellowship and a University of Queensland New Staff Research Grant to the first author supported this work. We thank Mala McHale and Daniel Johnson for their assistance with data collection. Aspects of the data were presented at the 2000 meeting of the Canadian Psychological Association in Ottawa, Ontario, Canada.

\section{References}

Aiken, L. S., \& West, S. G. (1991). Multiple regression: Testing and interpreting interactions. Newbury Park, CA: Sage.

Bollen, K. A., \& Hoyle, R. H. (1990). Perceived cohesion: A conceptual and empirical examination. Social Forces, 69, 479-504.

Branscombe, N. R., Ellemers, N., Spears, R., \& Doosje, B. (1999). The context and content of social identity threat. In N. Ellemers, R. Spears, \& B. Doosje (Eds.), Social identity: Context, commitment, content (pp. 35-58). Oxford: Blackwell.

Breakwell, G. M. (1983). Formulations and searches. In G. M. Breakwell (Ed.), Threatened identities (pp. 3-26). Chichester, UK: Wiley.

Cameron, J. E. (2001). Social identity, modern sexism, and perceptions of personal and group discrimination by women and men. Sex Roles, 45, 743-766.

Cameron, J. E. (2004). A three-factor model of social identity. Self and Identity, 3, 239-262. 
Cameron, J. E., \& Lalonde, R. N. (2001). Social identification and gender-related ideology in women and men. British Journal of Social Psychology, 40, 59-77.

Cialdini, R. B., Borden, R. J., Thorne, A., Walker, M., Freeman, S., \& Sloane, L. R. (1976). Basking in reflected glory: Three (football) field studies. Journal of Personality and Social Psychology, 34, 366-375.

Cohen, J., \& Cohen, P. (1983). Applied multiple regression/correlation analyses for the behavioral sciences (2nd ed.). Hillsdale, NJ: Erlbaum.

Deaux, K. (1996). Social identification. In E.T. Higgins \& A.W. Kruglanski (Eds.), Social psychology: Handbook of basic principles (pp. 777-798). New York: Guilford.

Deaux, K., Reid, A., Mizrahi, K., \& Cotting, D. (1999). Connecting the person to the social: The functions of social identification. In T. R. Tyler, R. M. Kramer, \& O. P. John (Eds.), The psychology of the self (pp. 91-113). Hillsdale, NJ: Erlbaum.

Doosje, B., Branscombe, N. R., Spears, R., \& Manstead, A. S. R. (1998). Guilty by association: When one's group has a negative history. Journal of Personality and Social Psychology, 75, 872-886.

Doosje, B., \& Ellemers, N. (1997). Stereotyping under threat: The role of group identification. In R. Spears, P. J. Oakes, N. Ellemers, \& S. A. Haslam (Eds.), The social psychology of stereotyping and group life (pp. 257-272). Oxford: Blackwell.

Doosje, B., Ellemers, N., \& Spears, R. (1995). Perceived intragroup variability as a function of group status and identification. Journal of Experimental Social Psychology, 31, 410-436.

Doosje, B., Ellemers, N., \& Spears, R. (1999). Commitment and intergroup behavior. In N. Ellemers, R. Spears, \& B. Doosje (Eds.) Social identity: Context, commitment, context (pp. 84-106). Oxford: Blackwell.

Doosje, B., Spears, R., \& Koomen, W. (1995). When bad isn't all bad: Strategic use of sample information in generalization and stereotyping. Journal of Personality and Social Psychology, 69, 642-655.

Duck, J. M., Lalonde, R. N., \& Weiss, D. (2003). International images and mass media: The effects of media coverage on Canadians' perceptions of ethnic and race relations in Australia. Australian Journal of Psychology, 55, 15-23.

Ellemers, N., Kortekaas, P., \& Ouwerkerk, J. W. (1999). Self-categorisation, commitment to the group and group self-esteem as related but distinct aspects of social identity. European Journal of Social Psychology, 29, 371-389.
Ellemers, N., Spears, R., \& Doosje, B. (1997). Sticking together or falling apart: In-group identification as a psychological determinant of group commitment versus individual mobility. Journal of Personality and Social Psychology, 72, 617-626.

Haslam, S. A., Oakes, P. J., McGarty, C., \& Turner, J. C. (1996). Stereotyping and social influence: The mediation of stereotype applicability and sharedness by the views of in-group and out-group members. British Journal of Social Psychology, 35, 369-397.

Hogg, M. A., \& Abrams, D. (1990). Social motivation, self-esteem and social identity. In D. Abrams \& M. A. Hogg (Eds.), Social identity theory: Constructive and critical advances (pp. 28-47).

London: Harvester Wheatsheaf.

Hornsey, M. J., Oppes, T., \& Svensson, A. (2002). 'It's OK if we say it, but you can't': Responses to intergroup and intragroup criticism. European Journal of Social Psychology, 32, 293-307.

Jackson, J. W. (2002). Intergroup attitudes as a function of different dimensions of group identification and perceived intergroup conflict. Self and Identity, 1, 11-33.

Jackson, J. W., \& Smith, E. R. (1999). Conceptualizing social identity: A new framework and evidence for the impact of different dimensions. Personality and Social Psychology Bulletin, 25, 120-135.

Kelly, C. (1989). Political identity and perceived intragroup homogeneity. British Journal of Social Psychology, 28, 239-250.

Kelly, P. (1998). Hanson-Symptom of a deeper problem. In N. I. Davidoff (Ed.), Two nations: The causes and effects of the rise of the One Nation Party in Australia (pp. 89-102). Melbourne: Bookman Press.

Kennedy, F. (1998, June 27-28). Hanson flak impact wide. The Weekend Australian, p. 44.

Kippax, S., \& Brigden, D. (1977). Australian stereotyping: A comparison. Australian Journal of Psychology, 29, 89-96.

Lalonde, R. N. (2002). Testing the social identity-intergroup differentiation hypothesis: 'We're not American eh!' British Journal of Social Psychology, 41, 611-630.

Lee, Y. T., \& Ottati, V. (1995). Perceived in-group homogeneity as a function of group membership salience and stereotype threat. Personality and Social Psychology Bulletin, 21, 610-619.

Luhtanen, R., \& Crocker, J. (1992). A collective self-esteem scale: Self-evaluation of one's social identity. Personality and Social Psychology Bulletin, 18, 302-318. 
Manne, R. (1998). Foreword. In N. I. Davidoff (Ed.), Two nations: The causes and effects of the rise of the One Nation Party in Australia (pp. 3-9). Melbourne: Bookman Press.

Rothgerber, H. (1997). External intergroup threat as an antecedent to perceptions of in-group and outgroup homogeneity. Journal of Personality and Social Psychology, 73, 1206-1212.

Simon, B., \& Brown, R. (1987). Perceived intragroup homogeneity in minority-majority contexts. Journal of Personality and Social Psychology, 53, 703-711.

Simon, B., Pantaleo, G., \& Mummendey, A. (1995). Unique individual or interchangeable group member? The attenuation of intergroup differences versus similarities as an indicator of the individual self versus the collective self. Journal of Personality and Social Psychology, 69, 106-119.

Spears, R., Doosje, B., \& Ellemers, N. (1997). Selfstereotyping in the face of threats to group status and distinctiveness: The role of group identification. Personality and Social Psychology Bulletin, 23, 538-553.

Spears, R., Doosje, B., \& Ellemers, N. (1999). Commitment and the context of social perception. In N. Ellemers, R. Spears, \& B. Doosje (Eds.), Social identity: Context, commitment, content (pp. 59-83). Oxford: Blackwell.

Tajfel, H. (1978). Differentiation between social groups. London: Academic Press.

Tajfel, H., \& Turner, J. C. (1979). An integrative theory of intergroup conflict. In W. G. Austin \& S. Worchel (Eds.), The social psychology of intergroup relations (pp. 33-47). Monterey, CA: Brooks-Cole.

Turner, J. C., \& Brown, R. J. (1978). Social status, cognitive alternatives and intergroup relations. In H. Tajfel (Ed.), Differentiation between social groups (pp. 201-234). London: Academic Press.

Turner, J. C., Hogg, M. A., Oakes, P. J., Reicher, S. D., \& Wetherell, M. S. (1987). Rediscovering the social group: A self-categorization theory. Oxford: Blackwell.

Turner, J. C., Hogg, M. A., Oakes, P. J., \& Smith, P. M. (1984). Failure and defeat as determinants of group cohesiveness. British Journal of Social Psychology, 23, 97-111. van Knippenberg, A. (1989). Strategies of identity management. In J. P. van Oudenhoven \& T. M. Willemson (Eds.), Ethnic minorities: Social psychological perspectives (pp. 59-76). Amsterdam: Swets \& Zeitlinger.

Wann, D. L., \& Branscombe, N. R. (1990). Die-hard and fair-weather fans: Effects of identification on BIRGing and CORFing tendencies. Journal of Sport and Social Issues, 14, 103-117.

Paper received 5 July 2003; revised version accepted 13 August 2004.

\section{Biographical notes}

JIM CAMERON is an associate professor at Saint Mary's University in Halifax, Nova Scotia, Canada, where he has taught since 1999. He is interested in the nature and consequences of social identification, particularly with respect to intergroup attitudes, collective action, psychological well-being, and globalization.

JULIE M. DUCK is a senior lecturer in the school of psychology at the University of Queensland, Australia. Her research interests include social identity, social comparison, persuasion and attitude change, and the social psychology of mass media use.

DEBORAH J. TERRY is a professor of social psychology in the school of psychology at the University of Queensland, Australia. Her research interests are in the areas of group processes, intergroup relations, attitude-behavior relations, and social influence.

RICHARD N. LALONDE is a French Canadian social psychologist at York University in Toronto, Canada. His research examines a variety of fundamental processes in intergroup relations, with a particular focus on issues of ethnic, cultural, and national identity. He is also interested in the study of immigrant acculturation and bicultural identification. 